\title{
Impact of Onset of Monsoon on the Incidence of Soybean Leaf Feeders
}

\author{
Mahendra Bele*, Rajesh Verma and Mukesh Dhakad \\ R.A.K. College of Agriculture, Sehore-466001, (M.P.), India \\ *Corresponding author
}

\begin{tabular}{|l|}
\hline Ke y w or d s \\
$\begin{array}{l}\text { Soybean leaf } \\
\text { feeders, Gesonia } \\
\text { gemma }\end{array}$ \\
\hline Article Info \\
\hline $\begin{array}{l}\text { Accepted: } \\
\text { 04 March } 2018 \\
\text { Available Online: } \\
\text { 10 April 2018 }\end{array}$ \\
\hline
\end{tabular}

A B S T R A C T

Incidence of (Grey semilooper) Gesonia gemma and Green semilooper (Chrysodeixis acuta) were also recorded on four dominate varieties (JS-335, JS-95-60, JS-93-05, RVS 2001-4) in soybean. Minimum of maximum temperature also shows declining trend. Rise of minimum temperature was $0.1084^{\circ} \mathrm{C}$ from the 2009 to 2014 kharif season as compared to normal temperature. Minimum of minimum temperature shows (rising) ascending trend indicated the rise of temperature. Mean temperature difference in the period study indicated rise of $0.462^{\circ} \mathrm{C}$ was observed. Rainfall shows declining trend. As compared to normal rainfall it decreased by $352 \mathrm{~mm}$, over the period of time. At the same time rainy days raised as 6.39 rainy days. Frequency of heavy to very heavy and extraordinary heavy rainfall shows increasing trend while frequency of light rainfall was in decreasing trend. Relative humidity increased by $3.7 \%$ in kharif as compared is normal in $2009-14$. Decadal trend was decreasing in case of temperature, while increasing in case of rainfall and relative humidity. Incidence of Chrysodeixis acuta and Gesonia gemma was statistically at par in soybean verities JS-335, JS-9560, JS- 9305, and RVS- 2001-4. Date of arrival of monsoon and sowing date of crop, not correlated with the incidence of Chrysodeixis acuta and Gesonia gemma. Larval population of Chrysodeixis acuta was significantly correlated with the difference of sowing date and date of arrival of monsoon. However larval population of Gesonia gemma was not correlated. Larval population of Gesonia gemma increases with the increase of maximum temperature, but population of Chrysodeixis acuta decrease with the rise of maximum temperature. Larval population of Gesonia gemma was negatively correlated with minimum temperature. While it was not correlated with the larval population of Chrysodeixis acuta. Difference of maximum temperature and minimum temperature had positive impact on larval population of Gesonia gemma while no impact on Chrysodeixis acuta larval population Larval population of Chrysodeixis acuta positively correlated with relative humidity while Gesonia gemma not. Larval population of Chrysodeixis acuta was negatively correlated with rainfall while Gesonia gemma not. The larval incidence of Chrysodeixis acuta and Gesonia gemma was less when population appearance late in the season.

\section{Introduction}

According to inter-governmental panel on climate change it is defined as "change in climate over time, either due to nature viability or as a result of human activity" occurrence of climate change is evident from increase in global average temperature change in monsoon activity and the rainfall pattern and extreme climate events. These seasonal 
and long term changes would affect the fauna, flora, population dynamics and status of insect pests. These may arise not only as a result of direct effects on the distribution and abundance of pest populations but indirect effects on the interaction of pests and host plants competition and natural enemies, (Porter et al., 1991).

Climate change results in occurrence of more frequent disasters with high magnitude and intensity. There is an increasing trend in the surface temperature of the country. This will adversely affect the rainfall pattern in the country as a result of which, agriculture and food security in the country will be severely affected. Climate change is likely to significantly affect agriculture by 2100 with wide variation in the estimation of impact on crop yields across different regions. The principal drivers of climate changer are increase of temperature reduced the biomass and yields of various crops. Temperature is identified as the dominant a biotic factor directly affecting the insects. There is little evidence of any direct influence of $\mathrm{CO}_{2}$ on insect and mostly the impact of elevated $\mathrm{CO}_{2}$ is mediated through host crop, particularly in case of herbivorous or phytophagous insects.

Effects of climate change on insect herbivores can be direct (temperature) through impacts on their physiology and behavior, or indirect, where the insect respond to climate- induced changes mediated through other factors, such as host plant induced growth changes. Weather and its significant interaction with key pests of several crops known among researchers and farming community. Pest surveillance and monitoring in relation to weather can considerably reduce the case of chemicals. In order to fine tune the existing pest predictions, understanding the thermal requirements and degree days for key pests and their associated natural enemies are of prime importance (Srinivasarao et al., 2010).
Green semilooper" Chrysodeixis acuta (Walker) (Noctuidae; Lepidoptera) is a serious pest of soybean crop. In severe out beaks, the pest may cause reduction of about 50 per cent in grain yield (Singh and Singh, 1987 b). Grey semilooper, Gesonia gemma (Swinhoe), a serious and most regular defoliators of soybean causes maximum damage during the month of September, which inflicts significant reduction in pod number, pod weight, grain number and grain weight of 3.94q/ha (Singh and Singh,1989 a).

Work on Impact of climatic change of incidence on soybean Grey semilooper (Gesonia gemma) and Green semilooper (Chrysodeixis acuta) were carried out to find out the weather fluctuation during kharif season experienced in last six years and its impact on the incidence of Grey semilooper, Gesonia gemma and Green semilooper, Chrysodeixis acuta in soybean individually in respective years and collectively in the study period. Incidence of Gesonia gemma and Chrysodeixis acuta were also recorded in four dominate soybean varieties (JS-335, JS-9560, JS-93-05, RVS 2001-4).

Changing climatic situation influence various crops, affected growth and yield parameters and also influence the insect growth and development and occurrence of pests.

India is endowed with rich surface water resources but an extremely uneven spatial and temporal distribution of the rainfall, which is the primary source of surface waters, frequently results in severe water scarcity in some regions and flood hazards (Mujumdar, 2008). Due to the changing climate water resources will come under increasing pressure in Indian subcontinent. The climate affects the demand for water as well as the supply and quality particularly, in and semi- arid regions of India any shortfall in competition for water use for a wide range of economic, social and 
environmental applications (Lioubimtsweva and Henebry, 2009)

Global warming is the root cause of climate change all over the world. Most of the changes in climate such as irregular monsoon, drought, temperature rise, cyclones, heavy rainfall etc due to rise in temperature. Climate change has tremendous effect directly or indirectly on cropping pattern, crop production and productivity. At local and regional levels the tendency and distribution of these parameters are influenced by geographical situations. It is therefore, necessary that the changes of rainfall and temperature pattern are quantified taking into duration of the long term data available for the locality (Sahu et al., 2010). It is projected that by the end of the 21 st century rainfall will increase by $15-31 \%$, and the mean annual temperature will increase by $3^{0} \mathrm{C}$ to $6^{0} \mathrm{C}$. Increasing climatic variability associated with global warming will, nevertheless, result in considerable seasonal/ annual fluctuation in food production. (Verma et al., 2010).

Singh et al., (2011) observed sixteen insect pests and one mite on soybean at different growth stages, of which, five belonged to order Lepidoptera, five to Coleoptera, two to Hemiptera and Orthoptera, one each to Thysanoptera, Diptera and Acarina of these two were stem borers, nine defoliators, one root feeder, one pod feeder and four sap feeders.

Crop production in dry land is purely dependent on rainfall. Hence, for a successful cropping in dry land scientific evaluation of rainfall of a region is imperative (Kannan et al., 2000). Venkataraman et al., (2009) had earlier reported that pre-monsoon sowing of cotton should be taken up at 39th standard week. This condition will be applicable of these was a probability of 75 per cent to get a rainfall of $25 \mathrm{~mm}$. But pre- monsoon sowing of crops in the recent years failed due to nonreceipt of pre- monsoon rains.

The soybean yield under elevated temperature ( 1 to $5^{0} \mathrm{C}$ over current temperature) and $\mathrm{CO}_{2}$ concentration (450 and $550 \mathrm{ppm}$ ) for three locations (Indore, Nagpur and Dharwad). Data also indicated that if $\mathrm{CO}_{2}$ effects are not considered, the soybean yields declined at all the locations. The overage reduction in yield ranged from $5 \%$ with $1{ }^{\circ} \mathrm{C}$ rise in temperature to $35 \%$ with $5^{\circ} \mathrm{C}$ rise in temperature over current temperatures.

Comparative study of seven years weather data on occurrence of early blooming and its relation with the incidence of leafhopper Indeoscop usniveopareus in mango, revealed that the rise of leaf hopper population was coupled with the early initiation of inflorescence in mango orchards induced by rising trends of mean maximum temperature beyond $30^{\circ} \mathrm{C}$ in the months of October and November as compared to normal blooming season of mango (Verma and Swati, 2010).

Groundnut leafminer (GLM), Aproqerema modicella is the key pest of groundnut in many part of India particularly the southern states. This pest is favored by the host dry conditions of the post rainy season. Heavy persistent rains high relative humidity $(\mathrm{RH})$ and low temperatures reduced pest infestation, whereas dry weather, bright sunshine and occasional rains favored pest build up (Ghule et al., 1989). GML has been often a problems towards the end of the rainy season (September and October), especially in drought or low- rainfall years (Amin, 1983). GML population fluctuated widely between seasons. Amin (1987) and Khan and Raodeo (1987) have suggested that high rainfall reduces leaf minor populations even though data from the latter did not support this conclusion. They observed high populations in August September during a high rainfall 
period and populations declined in March when no rains was recorded (Rao et al., 2010).

Increased temperature influenced the larval development and fecundity of $O$. brymacta insects (Dury et al., 1998) and long term exposure to increased temperature $3.5^{\circ} \mathrm{C}$ shortened the insect development (Williams et al., 2003). The temperature enhancement increased the relative growth rate of Chrysomelia beetles (Veteli et al., 2002).

Sharma et al., (1997) observed that mean temperature around $26^{\circ} \mathrm{C}$ was most conducive for the population buildup of key pests of soybean. The correlation of weather parameters with the population buildup of semilooper, Thysanoplusia orichalcea (Fab.) Bihar hairy caterpillar, Spilosoma oblique (Walk); and leaf miner, Liriomyza trifoli (Burgess) were non-significant.

Singh and Kumar (2003) determined correlation between meteorological parameters (temperature and relative humidity) and population buildup of insect defoliators of cowpea. The incidence of grasshopper (Poekilocer uspictus), red pumking beetle (Raphidopalpa foveicollis, Aulacophora foveicollis), jute weevil (Apoinampulum), leaf miner (Phytomyza atricornis) and red hairy caterpillar (Amsacta moorei) was recorded from germination to harvesting stage at weekly interval.

Grasshopper infestation was observed in the $3^{\text {rd }}$ week of April at the early growth stage of cowpea and peaked during the $2^{\text {nd }}$ week of May and $2^{\text {nd }}$ week of June. The population of leaf miner peaked at the early stage of crop growth during the $3^{\text {rd }}$ week of April. Red pumpkin beetles were noticed in the $3^{\text {rd }}$ week of April and peaked of May. The appearance of jute weevil was noticed in the $1^{\text {st }}$ week of May and continued until crop maturity.
Larvae of red hairy caterpillar were recorded from vegetative stage to maturity; however, the population was very low during the entire crop growth. The population buildup of grasshopper, jute weevil and red hairy caterpillar was positively correlated with minimum and maximum temperatures, while the population buildup of leaf miner and red pumpkin beetle was positively correlated with relative humidity.

Singh (2010) recorded a total of sixteen insect-pests were recorded on Vigna mungo at different stages of crops growth during Kharif 1997 and 1998. The populations of grass hopper Epilachna beetle and leaf Webber were negatively correlated with relative humidity and rainfall during both the years.

Rai and Singh (2012) studied the effects of climatic factors on the incidence of jassid (Amrsca bijuttula) on okra (Kashi Pragati) in Uttar Pradesh, India, during the summer and rainy seasons of 2008 and 2009.

The jassid population was initially observed in the second week of April (mean density of 4.8 per 3 leaves), and its population peaked on the fourth week of May (mean density of 22.3 per 3 leaves).The population density was positively correlated with relative humidity minimum temperature, minimum relative humidity, rainfall, however sunshine hours did not bear any effect on the jassid population.

Khalid et al., (2013) studied the effect of the weather factors on incidence and development of Helicoverpa armigera on different sunflower genotypes during 2008-2009. The determination of the effects of different weather factors on egg count and larval population of $H$. armigera in sunflower was essential for effective management of this pest. 
Singh et al., (2013) observed 12 insect species during Kharif season of 2007 wherever 13 insect pests and one mite were observed on soybean during 2008 and 2009. These pests were identified as Gesonia gemma (Swinhoe), Chrysodeixis acuta (Walker), Spodoptera litura (Fab.), Helicoverpa armigera (Hub.), Myllocerus maculosus (Desbro). Gryllus sp.; Cneorane sp., Luperu sclytie (Wilcox) and Mocis undata, Stem borers viz. Obereopsis brevis (Swed.) and Melanagromyza sojae (Zehnt.); and sap feeders Bemisia tabaci (Gennadius), and Chauliops fallax (Scott.). Of these, Cneorane sp., Gesonia gemma, Chrysodeixis acuta, Melanagromyza sojae and Obereopsis brevis were recorded as major pests. During 2007 the infestation reached up to 13.5 per cent, however during 2008-09 it was upto 26.6 and 30.5 per cent, respectively before harvesting of the crop.

Studies on impact of onset of monsoon on the incidence of Soybean leaf feeder Chrysodeixis acuta and Gesonia gemma were conducted at experimental field of College of Agriculture Sehore. Delay of arrival of monsoon is determined by various factors and it imposed the effect on crop sowing, crop growth and activity of insect pests.

Determination of onset and withdrawal of monsoon depends upon the 14 meteorological parameter, two of which represent heating over north Asia-Middle East sector and Tibet - Himalaya karakoram-Hindukush Highlands; two intensity of the general atmospheric circulation over eastern hemisphere, three intensity of regional circulation and seven local hydrometer logical condition (Singh and pandey 2010).

Circulations of southwest monsoon not seem to exist any on field objective criterion for on set and withdrawal of south west monsoon (Rai and Rajeevan 2009).
In central India normally the monsoon arrive in third week of June and the sowing of kharif done between fourth week of June to first week of July depending up on the mutation activity of Soybean leaf feeders initiated in around third week of July. Pests' activity during past six years from 2009- 2014 in relation to monsoon arrival and relation climate change activities were studied kharif season was considered from June last to first week of October.

\section{Results and Discussion}

\section{To study the weather fluctuations recorded} during last six years in the study area

Overall result indicated that the trend of maximum temperature in the study year 2009 to 2014 decline by $0.149^{\circ} \mathrm{C}$ as compare to the normal temperature the decline was liner. However the deviation of maximum temperature from the normal in the study period showed declining trend $(\mathrm{y}=$ $0.199 x+0.975)$. Similarly the minimum of maximum temperature also show linear declining trend $(y=-0.507 x+28.41)$

Thus it is indicated from that the mean deviation of the minimum temperature was $1.29,0.401,0.33,-0.17,0.92^{0} \mathrm{C}$ in Kharif season 2009, 2010, 2011, 2012, 2013 and 2014 respectively. The data further indicated that the minimum of maximum temperature in the study period was in rising trend $(\mathrm{y}=$ $0.303 x+19.23)$ and the mean deviation of minimum temperature from the normal temperature showed the rising trend $(\mathrm{y}=$ $0.279 x-0.870)$. The rise of minimum temperature during the study period was $0.108^{0} \mathrm{C}$ as depicted by the comparative account data of seasons mean with the normal minimum temperature. The mean difference between the maximum and minimum temperature. During the study period 2009 2014 was $0.001717^{\circ} \mathrm{C}$ However the data of 
year wise difference between maximum and minimum temperature showed linear decline in temperature difference as compared to the normal by $\mathrm{y}=-0.352 \mathrm{x}+1.94 \mathrm{R}^{2}=0.202$.

Rainfall pattern in the study period was erratic and total rainfall showed the decline trend $\mathrm{y}=$ - 8.342x - 298.5 $R^{2}=0.005$. The mean decline in rainfall as compared to normal was 352.8 $\mathrm{mm}$. The frequency of light rainfall $(0-$ $64.4 \mathrm{~mm})$ shows declining trend $(\mathrm{y}=$ $0.542 x+12.73$ ) while the frequency of heavy and very heavy 64.4 to $124.4 \mathrm{~mm}$ and extra ordinary very heavy rainfall (above 124.4 $\mathrm{mm}$ ) rainfall were showed rising trend $\mathrm{y}=$ $0.428 x+2.666$ and $y=0.028 x+1.733$ respectively. Normal rainy days in kharif season is 70.61 the rainy days in 2009, 2012, 2011, 2012, 2013, 2014 were 62,80,83 and 80 , days respectively which was 3.61 days less in 2009 and 9.39, 12.39, 9.39, 9.39 days higher in 2010 to 2014 respectively The mean increase in rainy days was 6.39 days.

Temperature change of maximum was also compared with the data of maximum temperature of last 3 decades present in (1984 to 1983) the mean maximum temperature of kharif season was 31.43 that was raised $0.158^{\circ} \mathrm{C}$ in next decades (1994 to 2003) and in proceeding decade decreased by $0.428^{0} \mathrm{C}$ then thus trend of maximum temperature in the last 3 decades show declining $(y=-0.171 x+31.72$ $\left.\mathrm{R}^{2}=0.705\right)$ with fluctuation of mean temperature +0.158 and $-0.428{ }^{\circ} \mathrm{C}$ However in the study period $2009-2014$. The mean maximum temperature was decreased by $0.392^{\circ} \mathrm{C}$ as compared to last decades while comparing the fluctuation within the study period 2009 to 2014 maximum temperature raised by $0.279^{\circ} \mathrm{C}$ as compared to mean normal temperature.

The data of minimum temperature of last 3 decades indicated the fluctuating trend. In first decades 1984 to 1993 mean minimum temperature was $22.59{ }^{0} \mathrm{C}$. It was rise by 0.5 next decades 1994 to 2003 and again gown down by $\mathrm{y}=-0.016 \mathrm{x}+22.63 \mathrm{R}^{2}=0.159$ $0.083^{0} \mathrm{C}$. Overall result indicates that during the study period $2009-2014$. The minimum temperature raised by $0.48{ }^{\circ} \mathrm{C}$ as compared to the mean of last 3 decades temperature, while within the study period minimum temperature show rising trend and the mean temperature was $0.108{ }^{0} \mathrm{C}$ as compared to normal temperature.

Difference of maximum and minimum temperature like indicated the decreasing trend $\mathrm{y}=-0.118 \mathrm{x}+9.032 \mathrm{R}^{2}=0.170$ in last 3 decades. During the study period 2004-2014 kharif season the fluctuation difference of temperature was indicated slide rise that is $0.0017{ }^{0} \mathrm{C}$ as compared to the normal.

Rain fall data of kharif season in last 3 decades indicated the cyclic fluctuation rainfall experienced $1419.1877 .02,1521.9$ and $826.44 \mathrm{~mm}$ in 1984-2003, 1904 - 2003, 2004- 2014 and 2009 - 2014 respectively. Relative humidity indicated the gradual increase in last 3 decades including the study period 2009 to $2014\left(\mathrm{y}=1.555 \mathrm{x}+66.24 \mathrm{R}^{2}=\right.$ 0.975) while within the study period the relative humidity increase by $3.735 \%$.Monthly data of kharif season indicated decadal shift of relative humidity in last 3 decades.

\section{To find out the incidence of Chrysodeixis} acuta (Walker) and Gesonia gemma (Swinhoe) on some popular varieties of soybean

Activity of the Gesonia gemma on different variety of soybean was observed at low level. The season mean of pest population $2 / \mathrm{mrl}$ was 1.086 in JS - 335, 1.551 JS- 95-60, 1.261 in JS-9305, and 1.212 RVS 2001-4 varieties respectively statistical the incidence of pest in difference varieties was non-significant. 
Larval population of Chrysodeixis actua was also remained at very low level in all the four varieties of soybean. The mean population of the season was 1.343 larvae per 2 meter row length, in JS 335, 2.367 larvae per $2 \mathrm{mrl}$ in JS 9560, 1.253 larvae per $2 \mathrm{mrl}$ in JS 9305 and 1.187 in RVS 2001-4 variety respectively the differenced were statically non significance. The decreasing trend in larval population of Gesonia gemma probability due to the Climate change, minimum temperature 0.108 ${ }^{0} \mathrm{C}$, relative humidity $3.735 \%$ and rainy days 6.397 and increase of intensity of very heavy to exception rainfall during the kharif season.

\section{To find out the co-relation between weather factors and incidence of Chrysodeixis acuta (Walker) and Gesonia gemma, (Swinhoe) on soybean}

In Sehore district the earliest date of monsoon arrival was 11 June in kharif 2013 and the delay arrival of monsoon 4 July was observed in 2012. The arrival date of monsoon was converted in to numeric number by counting the days started from first June for example if the monsoon arrived from $28^{\text {th }}$ of June the number allotted of 28 and so on. The date indicated that date of the sowing crop various in different years from the date of arrival monsoon.

The correlation study reveal that the population of Chrysodeixis acuta was significantly co related with the date of sowing days after the arrival of monsoon $(r=$ 0.631). Similarly the date of arrival of monsoon and sowing date of crop had no significant Impact on the occurrence of pest. However the trend was negative $(r=-1.44)$, $(\mathrm{r}=-0.174)$ in case of Gesonia gemma and Chrysodeixis acuta respectively.

Maximum temperature during the study period was not co related with the pest population of Gesonia gemma. Population of
Chrysodeixis acuta was significantly and positively co related with maximum in 2010 and 2013 kharif season. The season's mean of maximum temperature of 2009 to 2014 was significantly correlated with the season's mean population of Gesonia gemma $\mathrm{r}=0.516$ while the co relation was significant but negative in case of Chrysodeixis acuta $\mathrm{r}=$ 0.474 . The mean of the season's population of Gesonia gemma correlated significantly with the minimum temperature the co relation was negative $\mathrm{r}=-0.653$. Larval population of Chrysodeixis acuta was positively $\mathrm{r}=0.563$ co related with minimum temperature.

Mean temperature were not influences the larval population of Chrysodeixis acuta the co relation was non-significant in all the years while mean temperature had positive impact on the occurrence larval population of Gesonia gemma in 2011( $\mathrm{r}=0.504)$ and 2012 $(\mathrm{r}=0.455)$ the co related was positive.

The mean larval population of Gesonia gemma of different years was significantly and positively co related with the difference of maximum and minimum temperature. $(\mathrm{r}=$ 0.597). While the data of season's mean of Chrysodeixis acuta population was not co related with the seasons mean of difference of maximum and minimum temperature. The season mean data of larval population of Gesonia gemma was not correlated with the rainfall $\mathrm{r}=-0.054$, while it was negatively correlated with the larval population of Chrysodeixis acuta $(\mathrm{r}=-0.738)$

Data of first appearance of pest in day after germination was correlated with the mean larval population of the season the correlation was negative and significant $r=-0.818$. Thus it is indicated that the population appear early in the season the incidence was more but in case of Chrysodeixis acuta the data reveal that the incidence of the pest was less when population appear late in the season (DAG). 


\section{Maximum temperature}

Declined by $0.149^{\circ} \mathrm{C}$ as compared in the study period 2009- 2014 kharif. Minimum of maximum temperature also shows declining trend.

\section{Minimum temperature}

Rise of minimum temperature was $0.1084^{\circ} \mathrm{C}$ from the 2009 to 2014 kharif season as compared to normal temperature. Minimum of minimum temperature shows (rising) ascending trend indicated the rise of temperature.

\section{Difference of maximum and minimum temperature rainfall}

Mean temperature difference in the period study indicated rise of $0.462^{\circ} \mathrm{C}$ was observed. Rainfall shows declining trend. As compared to normal rainfall it decreased by $352 \mathrm{~mm}$, over the period of time. At the same time rise of rain fall increased to 6.39 rainy days. Frequency of heavy to very heavy and extraordinary heavy rainfall shows increasing trend while frequency of light rainfall was in decreasing trend.

\section{Relative humidity}

Relative humidity increased by $3.7 \%$ in kharif as compared is normal in $2009-14$.

\section{Decadal shift}

Decadal trend was decreasing in case of temperature while increasing in case of rainfall and relative humidity.

Incidence of Chrysodeixis acuta and Gesonia gemma swas statistically at per in soybean verities JS-335, JS-9560, JS- 9305, and RVS2001-4. Date of arrival of monsoon and sowing date of crop was not correlated with the incidence of Chrysodeixis acuta and Gesonia gemma. Larval population of Chrysodeixis acuta was significantly correlated with the difference of sowing date and date of arrival of monsoon. However larval population of Gesonia gemma was not correlated. Larval population of Gesonia gemma increases with the increase of maximum temperature, but population of Chrysodeixis acuta decrease with the rise of maximum temperature.

Larval population of Gesonia gemma was negatively correlated with minimum temperature. While it was not correlated with the larval population of Chrysodeixis acuta. Difference of maximum temperature and minimum temperature had positive impact on larval population of Gesonia gemma while no impact on Chrysodeixis acuta larval population. Larval population of Chrysodeixis acuta positively correlated with relative humidity while Gesonia gemma not. Larval population of Chrysodeixis acuta was negatively correlated with rainfall while Gesonia gemma not. The larval incidence of Chrysodeixis acuta and Gesonia gemma was less when population appearance late in the season.

\section{References}

Amin, P.W. (1983). Major field insect pests of groundnut in India and associated crop losses, special issue. India J. Entomol.2:337-344.

Amin, P.W. (1987). Insect pest of groundnut in India and their management In. Plant protection in field crops $\mathrm{Ed}$. By $\mathrm{M}$. Veerabhatra Rao, and S. Sithamntham, Pp. 219-233: Plant Protection Association of India Hyderabad.

Anonymous (2013) Directors Report and Summary Tables, AICRP on soybean (ICAR) pp 218-220. 
Babu, R; and Ragavan, T; (2010) Decadal Analysis of Rainfall data in the context of climate change and its impact on crop management in Kovilpatti, Tamil Nadu. National symposium on climate change and rain fed agriculture.

Bale, J., Gfegory J. Masters; Ian D. H.; Caroline A., T. Martizn, B.F. Valeriek Brown, J. Butterfield, AlanBuse, John C., Coulson; John, F; John E., G Good; Richard, Harringhton; Susane, Hartley; T., Hefin Jones; Richard, L.; Lindroth, Malcolm; C., Press; Ilias, symrnioudis; Allan, D watt; and John, B., Whittaker; S (2002). Herbivore in global climate change research: Direct effects of rising temperature on insect herbivores, Global change Biology8, 1- 16

Chattopadhyay, N., Samui, R. P., Wadekar, S. N.; Singh, A. R. and Kumar, N. G. (2002). Prediction of the incidence of soybean leaf miner based on weather parameters. Indian Journal of Entomology 64(3): 358-367.

Dewer, R.C; and Watt, A.D; (1992). Predicated change in the synchrony of larval emergence and budburst under climatic warming ecology, 89, 557-559.

Dury, S.J., Good, J.E.G., Perrins, C.M., Buse A. and Kaye, T. (1998). The effects of increasing $\mathrm{CO}_{2}$ and Temperature on oak leaf palatability and the implication for herbivorous insects. Change Biology, 4: $55-61$.

Garg, D.K. (1985). Soybean insect pests in Uttar Pradesh Hills of Western Himalayas. Pestology, 9(12): 5-7.

Gaston, K.J; and Williams, P.H (1996). Spatial patterns in taxanomic diversity. In Biodiversity (ed: Gaston I.J), Pp. 202 -229. Blackwell Science, Oxford.

Ghule, B.D.; Jagtap, A.B.; Dhumal, V.S. and Deokar, A.B. (1989) Influence of weather factors on the incidence of leaf miner (Aproarema Modicell Deventer) on groundnut. Journal of Oil Seeds Research, 6, 17 - 21.

Kannan, S.R., Babu, R., Bale Subramanian and Gurumurthi, J. (2000), Rainfall analysis and designing cropping pattern of Madurai region. Advances in Agriculture Research. 14:95-110,

Khalid Z; Anjum S; Arshad, M. and Arif, M. J.(2013).Impact of weather factors on population fluctuation of $H$. armigera on sunflower. Pakistan Journal of Nutrition, 12(1): 50-54.

Khan, M.I. and Raodeo, A.K. (1987). Season incidence of groundnut leaf miner, Aproaerema modkellad enenter (Lepidoptera: Gelchiidae). Punjabrao Krishi Vidyapeeth Res., 11: 93- 96

Kumar Verma, Praveen; Mishra, N.K., Thakur, D.S. and Patil, S.K. (2010) Impact of Climate change on Agriculture in scenario. National symposium on climate change and rain fed agriculture.

Lewin, H.D., Saroja, R., Leela David, A, and Pandmanabhan, M.D. (1979). Influence of sowing time and weather on the incidence of groundnut leaf miner. Indian. J. Agric. Sci., 49: 886-891.

Lioubimtseva, E. and Henebry G.M. (2009). Climate and environmental change in arid central Asia: Impacts, vulnerability and adaptations. Journal of Arid Environment, 30: 155.

Majumdar, P.P., (2008). Implications of climate change for sustainable water resources management in India, Physics and Chemistry of the Earth, 33: 354358.

Malgaya, J.L. (2013). Studies on the seasonal incidence, nature of damage and assessment of losses caused by girdle beetle, Thesis submitted to R.V.S.K.V.V., R.A.K. College of Agriculture Sehore (M.P.) pp. 25.

Parmesan, C., Ryrholm, N., Stefancescu, C., Hill, JK., Thomas, C.D., Descimon, H., 
Huntley, B., Kalla, L., Kulberg, J., Tammaru, T., Tnnent, W.J., Thomas, JS., and Warren, M. (1999). Poleward shifts in associated with regional warmins, Nature, 399, 579 - 583.

Pollard, E. and Yates, T.J. (1993) Monitoring Butterflies for Ecology and conservation. Chapman and Hall, London.

Porter, J.H.. Parry, M.L. and Carter, T.R. (1991). The potential effects of climatic change on agriculture insect pests. Agril and Forest Meteoral, 57(4): 221-240.

Rai, A.B. and Singh, S.N. (2012) Seasonal incidence of Amrasca biguttula on okra and its relationship with abiotic factors Annals of Plant Protection Science 20 (2): 469-470.

Rai, R. K. and Patel, R. K. (1990). Girdle beetle, Obereopsis brevis Swed. incidence in kharif soybean. Orissa Journal of Agricultural Research 3 (2): 163-165.

Sahu, D.D., Chopada, M.C., and Khacha H.L. (2010) Trend in Rainfall and temperature distribution over Saurashtra Region. National symposium on climate change and rain fed agriculture.

Sharma, D; Bagmare, A. and Gupta, A. (1997) Effect of weather parameters on population buildup of key pest of soybean. J. Insect Sci. 10 (2): 120-124.

Shrinivasrao, M, Rangarao, G.V, and Venkateshwarlu, B. (2010) Impact of climate change on Insect pests In: National Symposium on Climate Change and Rainfed Agriculture, 2010, CRIDA, Hyderabad. pp 43-53.

Singh A.K. and Kumar, S. (2003) Effect of meteorological parameters on population build-up of defoliators on cowpea. Annals of Plant Protection Sciences 11 (1): 156-158.

Singh O.P and Singh K.J. (1987 a). Green semilooper, Chrysodeixis acuta, as a pest of flowers and pods and its effect on the grain yield of soybean in Madhya Pradesh. Ind. J. Agric. Sci. 57(11):861863.

Singh H.M. (2010). Seasonal incidence of defoliators in Urd bean (Vigna mungo L. Hepper) and their correlation with meteorological parameters. International Journal of Plant Protection 3: 2,197-199

Singh S; Tomar A. Singh, and Nadaf A. (2013) Seasonal incidence of major insect-pests of soybean in Malwa region of Madhya Pradesh. BIOINFOLET - $A$ Quarterly Journal of Life Sciences, 10(4): 1520-1527.

Singh, C. B., Dandre, D., Singh, C., Pal, M. and Chourey, P. (2011). Incidence and damage of major insect pests of soybean. Flora and Fauna. 17(2): 273277.

Singh, N., and Pandey, A. (2010). Determination of onset and withdrawal dates of summer monsoon of summer monsoon across India using NGEP/ NCARRe analysis. National symposium on climate change and rainfed Agri. Feb 18-20 2010 CRIDA, Hyderabad. pp. 14.

Singh, O. P. and Singh K.J. (1989 a). Estimation of avoidable losses to soybean by grey semilooper, Rivula $\mathrm{sp}$. (Lepidoptera: Noctuidae) in Madhya Pradesh. J. Insect Sci., 2(1): 62-63

Singh, S.; Sil, S.; Chakraborty, A.; and Panda, S.N; (2010) Recent climate trend and its impact on precipitation. National symposium on climate change and rain fed agriculture.

Tupe, A.R., Bhale, V.M., Vanjari, S.S. and Farkade, B.K. (2010). Climatic variability in Akola district of western Vidarbha Region of Maharashtra In: National Symposium on Climate Change and Rainfed Agriculture, 2010, CRIDA, Hyderabad, Extended 
Summaries Vol. 2 (Session III, IV and V) pp 27-30.

Venkataraman, N.S., Ragavan, T.; Saravanan, T.; Rap, G.S.N. and Ramakrishna. Y.S. (2009), Agro climatic features and crop production in dryland tract of Kovilpatti., T.N. Technical Bulletin, AICRP on Agro meteorology, Agri. Res. Station, Kovipatti 628-501.

Verma, P.K., Mishra N.K., Thakur, D.S. and Patil, S.K. (2010). Impact of climate change on Agriculture in Indian scenario In: National Symposium on Climate Change and Rainfed Agriculture, 2010, CRIDA, Hyderabad, Extended Summaries Vol. 2. (Session III, IV and V) pp 51-53.

Verma, R.; and Singh, S. (2010) Climate change its impact on the incidence of mango leaf hopper, Idioscopur
Nivesparus Leth. In relation to early initiation of flowering in mango. National symposium on climate change and rain fed agriculture.

Veteli, T.O., Kuok kanen K, Julkunen-Tiitto $\mathrm{R}$, Roininen, $\mathrm{H}$. and Tahvanainen $\mathrm{J}$. (2002). Effects of elevated $\mathrm{CO}_{2}$ and temperature on plant growth and herbivore defensive chemistry. Global change Biology 8 (12): 1240-1252

Williams, R.S., Lincoln, D.E. and Norby, R.J. (2003). Development of gypsy moth larvae feeding on red maple saplings at elevated $\mathrm{CO}_{2}$ and temperature. Oecologia 137:114-122.

Williams, R.S., Norby, R.J., and Lincoln, D.E. (2000). Effects of elevated $\mathrm{CO}_{2}$ and Temperature - grown red and sugar maple on gypsy moth performance. Global Change Biology, 6: 685 - 695

\section{How to cite this article:}

Mahendra Bele, Rajesh Verma and Mukesh Dhakad. 2018. Impact of Onset of Monsoon on the Incidence of Soybean Leaf Feeders. Int.J.Curr.Microbiol.App.Sci. 7(04): 342-352. doi: https://doi.org/10.20546/ijcmas.2018.704.039 